\title{
What Iago Knew
}

\author{
Roberto Gigliucci ${ }^{1}$ \\ ${ }^{1}$ Sapienza University of Rome, Italy \\ Correspondence: Roberto Gigliucci, Sapienza University of Rome, Italy. E-mail: roberto.gigliucci@uniroma1.it
}

$\begin{aligned} & \text { Received: January 4, } 2018 \\ & \text { Accepted: January 30, } 2018 \quad \text { Online Published: February 8, } 2018 \\ & \text { doi:10.5539/ells.v8n1p45 }\end{aligned}$ URL: https://doi.org/10.5539/ells.v8n1p45

\begin{abstract}
This paper defines Iago as a master of time. He knows the future, or, even better put, he is able to foresee it quite brilliantly. Such an ability is typical of a Melancholy character, which, as known, can be a veritable villain. Iago instinctively knows that Desdemona will come to grow weary of the Blackamoor, and he detects her attraction to the young, handsome, and white Cassio. As head and meta-theatrical director, Iago sets out to compress time, and so exert pressure on the other characters. As a result, what would normally take place over a longer stretch of time, becomes quickly contracted in the space of a play. Moreover, considering how the 'future' is brought forward, the present appears more ambivalent. From Iago's point of view, is Desdemona a potential or an inevitable adulteress? To think the worst is, for the villain, to think realistically. Seeing time as following the rules of trivial consistency and verisimilitude (rendering the future predictable), makes it perfectly natural for Iago to consider Desdemona as an unfaithful woman, and Cassio, a coxcomb who plays around with other men's wives. Furthermore, the Moor is Black, and despite his "fairness", he will soon become a bad Negro again. Time will prove me right, Iago meditates. Thus, he zips time to triumph further and faster. The last section of the essay is dedicated to the occurrences of the word time in the play, with specific commentaries under the shadow of the secular exegesis, and in line with the critical assumptions made. Finally, in the discussion, the darker side of Iago is also explored, with careful assessment of the extensive bibliography on the subject.
\end{abstract}

Keywords: Shakespeare, Othello, Iago, time's compression

\section{Introduction}

On the 'glorious' stage of Elizabethan and Jacobean plays, the figures of the male lovers often become avengers, very often due to the women appearing to be loose or fornicators. 'Tis pity she's a whore is one of the most famous titles among the plays of John Ford (printed in 1633), requiring no further comment. Perhaps the most well-known example of such a scenario has been seen in Othello by Shakespeare (1603-1604), (Note 1) a paradigmatic case of foolish jealousy. Indeed, the common interpretation (Note 2) of this tragedy has been crystallised into seeing first, Desdemona as the unhappy, honest wife of the Moor, whom she loves with her life, then, the noble Othello as a passionate lover, (Note 3) but, believing her unfaithful through his own weakness, falls into the darkest of jealousies, and, finally, Iago, as an infamous villain, who sins just for sin's sake: the other characters are scarcely smart or definitely stupid, except for Emilia, Iago's spouse, who, in any case, comes to a bad end.

On the face of it, how the tragedy unveils seems to confirm this interpretation. But, in actual fact, here the tragedy of time is enacted, and the director of time is Iago. A considerable number of hermeneutical interpretations have been given to this character, one in particular being quite remarkable. In his old but keen Shakespearian monograph, Piero Rebora (Note 4) (brother of the poet Clemente) rejected the traditional image of Iago as a metaphysical devil, and reduced him to the level of a mere man, one very base, wicked, invidious, and vengeful, but still only a man. However, Iago is extraordinary clever, and has a deep insight into every human soul. As a critical (II, I, 120), satiric, Melancholy (Note 5) character, he is eagle-eyed, he is a smart villain, a ponderer, (Note 6) not a simple destroyer, as many other evildoers and butchers of English stage. He knows.

What does he know? He knows that, with the passing of time, things naturally evolve toward their inevitable destiny. Therefore, since the union between a black man and a white woman is unnatural, in a non-too distant future, Desdemona will tire of the Moor, and the young handsome Cassio, whom she already likes, shall be her paramour. The long tirade addressed to the dull Roderigo is a synopsis of the time Iago is contracting into a disfigured miniature (cf. II, I, 216-241). 
Lay thy finger thus, and let thy soul be instructed. Mark me with what violence she first loved the Moor, but for bragging and telling her fantastical lies. (Note 7) To love him still for prating? let not thy discreet heart think it. Her eye must be fed. And what delight shall she have to look on the devil? When the blood is made dull with the act of sport, (Note 8) there should be a game (Note 9) to inflame it and (to give satiety a fresh appetite) loveliness in favour, sympathy in years, manners and beauties-all which the Moor is defective in. Now, for want of these required conveniences, her delicate tenderness will find itself abused, begin to heave the gorge, disrelish and abhor the Moor; very nature will instruct her in it and compel her to some second choice. Now, sir, this granted (as it is a most pregnant (Note 10) and unforced position), who stands so eminent in the degree of this fortune, as Cassio does-a knave very voluble, no further conscionable (Note 11) than in putting on the mere form of civil and humane seeming, for the better compassing of his salt (Note 12) and most hidden loose affection? Why none, why none: - a slipper and subtle knave, a finder of occasions, that has an eye can stamp and counterfeit advantages (though true advantage never present itself), a devilish knave! Besides, the knave is handsome, young, and hath all those requisites in him that folly and green minds look after-a pestilent complete knave-and the woman hath found him already [II, i, 216-241, our italics].

\section{Iago and Cassio}

The hatred for Cassio is beyond doubt an acerb feeling nurtured by Iago. Yet, the insults (particularly knave, that unveils the social resentments of the Ensign) shift toward a rancorous admission of the Lieutenant's constant pulchritude and charm, which appear in stark contrast to Iago's unprepossessing qualities:

\section{If Cassio do remain, (Note 13)}

he hath a daily beauty in his life,

that makes me ugly [V, I, 18-20).

Some suspect of latent homosexual impulses in Iago have often been proposed (Note 14), with the whole tale of the erotic dream of the bed mate Cassio ("And then, Sir, would he gripe and wring my hand, / cry 'O, sweet creature!', and then kiss me hard, / as if he plucked up kisses by the roots / that grew upon my lips, then laid his leg / over my thigh”, II, III, 422-426) being certainly an image of grotesque homoerotism, something which induces feelings of horror in the Moor. Also, the particular of the handkerchief Iago confesses to have seen "Cassio wipe his beard with" (ibid. p. 440) appears risible, but Othello at this point is no longer fair (Note 15) and pure, but radically black, and sees everything black: "Arise, black Vengeance!" (ibid., p. 447), that is to say, enough about candour, purity and past glory, for I am black (ibid., p. 266). The racial and racist issue in Othello, has tormented many interpreters in the over the years. However, though this aspect cannot be ignored, it may not be a determining factor in fully understanding the tragedy. (Note 16) We suggest that the unlikely (but documented) possibility of a blackamoor becoming a noble condottiero in Venice, despite the racial prejudices and coeval commonplaces, is presented as an actual event at the beginning of the play. Only later on, the bias against Negroes (Note 17) is re-established by the realistic Iago, as confirmed by Othello's brutality. We may dream of a better and more candid world, but we know-Iago knows-how the world effectively works. Something similar appears in the dark comedy Winter's Tale, (Note 18) and in other problem plays by Shakespeare. "Iago invites his audience to take religious virtue as a part of the deluded official vision of human nature. Renaissance audiences must have been open to such materialist arguments and even atheistic opinions", (Note 19) writes Pechter. Underneath the mask of a malignant melancholy evildoer, Iago hides-though not from coeval public - an anti-idealizing acknowledgment of the true nature of human behaviour and the causal deterministic unfolding of events. Truth is pitiless, fiction merely offsetting and destined to vanish. As Ariosto saw Penelope as a whore, rather than the chaste wife poets had been glorifying (Orl. fur. XXXV, 27, 8), so too, following the pragmatic Weltanschaung by Iago, even sweet Desdemona can be suspected of being a potential harlot...

Coming back to the homoerotic shadow that might exist in Iago, we should first underline the fact that, despite his apparent self confidence, he actually despises himself, harbouring a deep desire to be someone different from himself: "were I the Moor, I would not be Iago" (I, I, 57). We could substitute Moor with Cassio, and it would be the same. The celebre conclusion "I am not what I am" (ibid. p. 65) (Note 20) is not only a declaration of programmatic deceitfulness. It means: I am not what I should be, I do not deserve the tawdriness and ugliness nature has condemned me to wear. In his disdain for the Moor and Cassio, Iago shows an intimate yearning to be like them. Moreover, the ardent desire to be like someone else is on the edge of carnal desire, as we learn from reading Freud or Mishima. (Note 21) In Giraldi Cinthio, the Alfiere was described as both extraordinarily beautiful and weak and perverse. (Note 22) Shakespeare shifts the attribute of beauty from the character of Iago 
to that of Cassio, and thus transforms even further the figure of the original Cinthian Alfiere into one of the most problematic of his theatrical personages. Even at the beginning of the play, Iago conceals his envy/desire through a virile and soldierly mockery of Cassio's inexperience and delicacy, debauchery and perhaps effeminacy. (Note 23) The tormented line 20 of the first scene of the first act, "a fellow almost damned in a fair wife" (depiction of Cassio by Iago), suggests perhaps a hint of 'womanliness' in the fop Cassio, and if we emended wife in wise the sense would become clearer. (Note 24) 'Effeminating' Cassio, Iago makes him not only a ladies' man but, deep down, a female object tout court, to be humiliated with sharp misogyny and to be lastly penetrated with a sword $(\mathrm{V}, \mathrm{I})$. Thus, Iago tries to manage his own grudge and discontent.

\section{An Enduring Problem: Who Is Iago?}

Despite being frustrated and secretly a sociopath, Iago is still far brighter than everyone else, and in the speech to Roderigo, he cleverly foresees future events, leaving no doubt as to his keen insight. He has quicky realized that Desdemona has a penchant for the handsome Cassio. Nothing serious, so far, but... frailty, thy name is woman, and every woman is potentially a prostitute, in the Elizabethan Stage. This vitriolic pragmatism of Iago is a rough but true-to-life realism, fruit of an experienced watchfulness of human existence. The fact that Iago himself may be motivated by jealousy, suspecting his own wife of having lied about both the Moor and Cassio (cf. I, III, 375-379; II, I, 286-290, and 298) is barely touched upon in two monologues given by the Ensign, an eye-for-an-eye sort of thing, but this can be overlooked. (Note 25) In the monologue of II, I there is also a hint of desire on Iago's part for Desdemona, "not out of absolute lust" (283), but "revenge". This has no link with the rest of the events, so it may be a sort of relic of the Cinthian plot: in the tale of Hecatommithi, in fact, the Alfiere falls in love with the Moor's wife and, as his love is unrequited, plans his vengeance.

The grudge against Cassio may be more influent, due to his promotion to Lieutenant and, above all, his beauty and charm, in contrast to Iago's ugliness and repugnancy (see above). His fool's paradoxes are evident, for instance, in the scene II, I with Desdemona and Emilia, when he displays misogynist double-entendres and profanities. Here, Iago is such an inexplicable and unfocused character that we may recognize a lustrous paradigm of the incoming Baroque complexity in him. He is a comedic clown, a natural born actor, (Note 26) a dark unblessed kin to Richard III (cheated of feature by dissembling nature), for some-such as Coleridge-a motiveless demon, for others a cool avenger; a Vice or even a Devil; (Note 27) a "self-made devil", or a "practical atheist"; (Note 28) he is the motor of the most tormented Shakespearian tragedy, he is intelligent and audacious, he is an underdog and a "Spartan dog" (Note 29) (5, II, 360), "inhuman dog" (V, I, 62), he is the alter ego of the tragedian, he is a creator, an artist, (Note 30) the shadow of Shakespeare himself, (Note 31) a story-maker, the father of a "monstrous birth" (I, III, 393, wonderful ending of the first act), the metteur en scène of a bloody farce, as Rymer sarcastically wrote, (Note 32) or even better, the director of a terrible domestic play of pitiful players who fret and fro, sliding towards death.

\section{Aristotelian Character}

Nevertheless, the real matter resides in Iago's brilliant plan concerning time. He connives to compress events, which should normally have entailed years to occur, into a couple of days, at the very most. (Note 33) He can be seen as an Aristotelian (dark!) character. To obtain this compression (Note 34) (fuelled by hatred, resentment and so on), Iago must work feigning, and bluffing everybody into doing exactly what he wants. Operating this way, he does not distort the nature and the destinies of his marionettes, but just speeds up a story that would have in any case unfolded in the same way. He is the puppeteer director, he is the motor, but he does not invent anything. Because he knows.

The total love of Othello for Desdemona is pure but fragile. Iago cultivates Othello's obsession, while contaminating Desdemona's chastity, (Note 35) allowing him to get Othello to shift his view of his wife from an angelical creature to that of a "lewd minx" (III, III, 475). The term honesty suffers many reversals during the play (not to mention the references to Iago of this attribute): (Note 36)

\section{DESDEMONA}

I hope my noble lord esteems me honest.

OTHELLO

O! ay; as summer flies are in the shambles,

that quicken even with blowing [IV, II, 65-67].

The repugnance of Othello for the new shape of his consort arises in a series of revolting images, (Note 37) the quote above being only one example. It is not easy to explain those verses: Desdemona's honesty is sarcastically 
compared to the flies that invade a slaughterhouse in a sweltering summer. With respect to the hard line 66, we can attempt a paraphrase: the flies get fatter, or become pregnant, even laying their eggs in the flesh. (Note 38) However, there is no hermeneutical certainty. (Note 39) Surely, Othello sees contortedly, as he sinks into an abyss of desperate revulsion. Iago has brought out the real obsessions of the Moor, merely hastening their coming to the surface. The wisdom of Emilia, Desdemona's maidservant, is shown at IV, III, 79-98, when she explains that women betray their husbands because of them, the husbands being violent, crazily jealous, unfaithful and so on; "Then, let them use us well: else let them know, / the ills we do, their ills instruct us so" (IV, III, 97-98). If the time of the play had not been quickened by the manoeuvres of Iago, would Desdemona have listened to the advice of Emilia? Yes, maybe she would have been persuaded to love another-Cassio of course-such as the "uncompromising" Lucrezia (nomen omen) in the Mandragola by Machiavelli. But time is pressing, and the tragic end is approaching. The disastrous folly of love is not caused by chance circumstances, as in Romeo and Juliet, but is provoked by the deterministic sequence of natural events that Iago has cynically compressed in a shorter time on stage.

\section{Is Desdemona an Adulteress?}

The relative time-paradox orchestrated by Iago provokes some curious and stunning superpositions, which become apparently illogic amalgamations. That is to say, future and present temporal overlapping affects identities, though not explicitly. For instance, Desdemona is a true, but also an unfaithful wife: she will undoubtedly be an adulteress in time, according to Iago, but for the active theatrical compression, she is a strumpet now. In the tale of Cinthio, we are told with moral accuracy that Desdemona fell in love with the Moor "tratta non da appetito donnesco, ma dalla virtù del Moro" (Note 40) ("impelled not by female appetite but by the Moor's virtue"). In the great scene of the Senate (I, III) Desdemona declares, in well-known verses:

My heart's subdued

even to the very quality of my lord:

I saw Othello's visage in his mind,

and to his honours and his valiant parts

did I my soul and fortunes consecrate [I, III, 248-252].

As in Cinthio, here we learn that the ardour of Brabantio's daughter for the Black warlord is not out of lust, but admiration for his innate qualities. However, reading the lectio of the Folio; the first Quarto had "utmost pleasure" in the place of "very quality" (Note 41) (v. 249). While taking into consideration philologists' choices and debates, we believe the different reading of $\mathrm{F}$ is one of its many corrections due to censure. To say publically "My heart's subdued / even to the utmost pleasure of my lord" is more problematical for Desdemona than in F's speech. To consider the utmost pleasure as something different from the total desire of the Moor, including his sexual satisfaction till the culmination of that pleasure, is ignoring the nuances of coeval theatrical expressions. Then, apart from the spiritual love for Othello, Desdemona feels a-yet not guilty-physical desire for the black man, (Note 42) despite the presumed age gap of 20 years or more: she sees him as powerful and charming, due to his past adventures, and his dark body of negro as an archetypal image of sexual prowess, if not alluring animality. This would explain Iago's acrid answer in the above quoted dialogue to Roderigo's depiction of the maiden "full of most blest conditions":

IAGO

Blest fig's end! The wine she drinks is made of grapes. If she had been blessed, she would never have loved the Moor. Blest pudding! (Note 43) Didst thou not see her paddle with the palm of his [Cassio's] hand? Didst not mark that?

\section{RODERIGO}

Yes, that I did—but that was but courtesy.

\section{IAGO}

Lechery, by this hand-an index and obscure prologue to the history of lust and foul thoughts. They met so near with their lips that their breaths embraced together. Villainous thoughts, Roderigo! when these mutualities so marshal the way, hard at hand comes the master and main exercise, th'incorporate conclusion, (Note 44) Pish! [II, I, 242-255, my italics].

Iago states that the Desdemona's choice of the Moor was out of lust (vv. 43-44 emphasized). Moreover, the paddle (Note 45) with the hands of the maiden and the young seductive Cassio can only be an indication of the 
girl's innate penchant for male beauty. Iago himself will cunningly depict Desdemona to Cassio as a generous person who "holds it a vice in her goodness not to do more than she is requested" (II, III, $308 \mathrm{f}$.). Desdemona is then almost likened to the Holy Virgin who, according to Dante Alighieri, anticipates the supplication with her immense kindness (see Commedia, Par. XXXIII, 16-21). Iago's hidden sarcasm could not be more evident, though his spiritual portrayal of Othello's wife is quite veracious. Iago seldom says untruths. He plays with reality (like with fire), foreseeing and contracting the events, and not fabricating falsehoods.

\section{Master of Time}

How the Ensign adopts the term "prologue" is quite theatrical, and marks just the start of his foreseeing of events, whose enactment he so hastens. Iago can be seen as the life of theatre. His theatre is not innocent, as time is not innocent - time spares no one. The ceremony of innocence is dead. "Innocence may be comfortable, but it is a comfort we [readers and spectators] are never allowed". (Note 46) We could perhaps recover a glimmer of innocence, living a normal time, or even stretching out time, to have more chances for avoiding mistakes. However, in a dimension of condensed time, evil is condensed as well, and with it, brutal effectiveness, that is beyond good and bad, constituting the background/habitat/humus of the transpiring evil. As Hazlitt exquisitely wrote,

"Our ancient" [Iago] is a philosopher, who fancies that a lie that kills has more point in it than an alliteration or an antithesis; who thinks a fatal experiment on the peace of a family a better thing than watching the palpitations in the heart of a flea in a microscope; who plots the ruin of his friends as an exercise for his ingenuity, and stabs men in the dark to prevent ennui. His gaiety, such as it is, arises from the success of his treachery; his ease from the torture he has inflicted on others. He is an amateur of tragedy in real life; (Note 47) and instead of employing his invention on imaginary characters or long-forgotten incidents, he takes the bolder and more desperate course of getting up his plot at home, casts the principal parts among his nearest friends and connections, and rehearses it in downright earnest with steady nerves and unabated resolution. (Note 48)

Histrio and capocomico, thus master of time, Iago ensnares actors (acting/living persons) in the trap of a black hole into which he himself eventually falls. A black hole or place of perfect total darkness, where everything collapses, consumed by quickened time-mutism, silence, the final curtain. Iago is the theatre, an art of time which fades into obscurity: a condensed time, a theatrical time, a perfect, albeit narrowed, speculum mundi.

\subsection{The Word Time}

As master of time, Iago actually pronounces this word, time, many times (apologies for the pun), precisely in 14 occurrences (ten in the verses, four in the prose), with regards to the 33 (26 "time", 7 "times") of the whole play. (Note 49) The word time passes his lips far more than it does for other characters, marking a relative frequency of 0.166 (deem that thy has 0.260 , and though 0.154 , so the word time is quite well placed). Let us quote and consider only a few passages where Iago pronounces the crucial word:

I, I, 31 "He, in good time, must his lieutenant be": naturally referred to Cassio; the form in good time could mean 'indeed' (ironical, expressing amazement, incredulity), (Note 50) but also 'soon, quickly'.

I, I, 47 "wears out his time", said about a servant who lives obeying his lord as an ass; the expression is encompassed in the complex Iago's speech that ends with the celebrated "I am not what I am".

I, III, 362-363 "There are many events in the womb of Time / which will be delivered": a fundamental passage, that anticipates the last words of the following monologue (and of the whole first act): "I have't, it is engendered! Hell and night / must bring this monstrous birth to the world's light". In both phrases, we grasp the metaphor of coming into being. Thus, the possible allusion to the motto veritas filia temporis seems less obvious, even though, according to Iago, the truth will actually be (and naturally is) monstrous.

I, III, 384 "after some time to abuse Othello's ears": we see the just above quoted ending of the monologue again "I have't! [...] to the world's light"; here "Iago gives a diabolical twist to the proverb he alluded to at 11. 362-363. Cf. also the related "Time brings the truth to light"“. (Note 51) "Some time" indicates the gradualness of Iago's acting; (Note 52) though the stages of his actions are a miniature of the naturally slower flow of time.

II, I, 260-261 "the time shall more favourably minister", with indirect object: "some occasion to anger Cassio". The Machiavellian theme of "occasion" becomes a main theme when Iago trains Roderigo.

II, III, 118 “on some odd time of his infirmity", said malignantly about Cassio; odd means 'casual', 'unexpected', but perhaps 'unavoidable' before or after... The "vice" or "infirmity" of drinking abuse, blamed by Iago on Cassio, will come to the fore in the future, till the whole of Cyprus shakes. In the scene of the fracas, Iago stages 
a verisimilar oddity, not an implausible truth. See Aristotle, Poetics, XXIV, 60 a 25-27. (Note 53)

II, III, 358 “Thou know'st we work by wit and not by witchcraft / and wit depends on dilatory time", another training for Roderigo. The opposition between wit and witchcraft is a claim to realism, in a frame of verisimilitude; consider the same word "witchcraft" in the speech of Othello at I, III, 169. The meaning of dilatory is debatable. (Note 54)

III, III, 249 "leave it to time", refers to the by now tormented Moor: every alike expression, for the reader, means 'leave it to $m e$ ', namely to the architect of time.

IV, I, 88 "But yet keep time in all", addressed now to a "most bloody" Othello; a warning to "maintain his self control', with a nuance of musical metaphor, but also 'all in good time', spoken in irony since Othello is now overhasty.

V, II, 301-302 "Demand me nothing: what you know you know; / from this time forth I never will speak word", last words of Iago, as everybody knows. Time has ended, the particular time manipulated by Iago. In a way, all the revels end tragically, in darkness and nothingness, as with every final curtain. The last syllable of recorded time stands still.

The meaningful use of time also occurs in the lines of other characters:

I, I, 160-161 [BRABANTIO] "and what's to come of my despised time / is naught but bitterness": the remaining time, for Desdemona's father, is one of complete sorrow.

I, II, 85-87 [BRABANTIO] "To prison, till fit time / of law and course of direct session / call thee to answer" (to Othello who has just asked him: "Whither will you that I go / to answer this your charge?"): a fit time that will never arrive, according to Brabantio's expectations.

I, III, 296-298 [OTHELLO] "Come, Desdemona, I have but an hour / of love, of worldly matter and direction / to spend with thee. We must obey the time" (presumably, to obey the time is a telling Shakespeare's coin of phrase).

III, III, 56, 63, 72; we quote from v. 55 to v. 77, with emphasis on words concerning time:

\section{DESDEMONA}

[...] Good love, call him (Note 55) back.

OTHELLO

Not now, sweet Desdemon—some other time.

\section{DESDEMONA}

But shall't be shortly?

OTHELLO

The sooner, sweet, for you.

DESDEMONA

Shall't be tonight, at supper?

OTHELLO

No, not tonight.

DESDEMONA

Tomorrow dinner, then?

OTHELLO

I shall not dine at home;

I meet the captains at the citadel.

\section{DESDEMONA}

Why then tomorrow night, or Tuesday morn,

on Tuesday noon, or night, on Wednesday morn-

I prithee name the time, but let it not

exceed three days. I'faith, he's penitent;

and yet his trespass, in our common reason- 
$[\ldots]$

When shall he come?

Tell me, Othello! I wonder in my soul,

what you would ask me, that I should deny,

or stand so mamm'ring on? (Note 56) What? Michael Cassio,

that came a-wooing with you, and so many a time,

when I have spoke of you dispraisingly,

hath ta'en your part- to have so much to do

to bring him in? By'r Lady, (Note 57) I could do much-

OTHELLO

Prithee no more: let him come when he will-

I will deny thee nothing.

Here we witness a juncture where it is Desdemona who now yearns to contract time, to exhaust her husband, as she has promised to Cassio: "My lord shall never rest, / I'll watch him tame and talk him out of patience" (III, III, 22-23). We may add that this very promise, and the fulfilment of same represent Desdemona's death sentence. Iago will be concerned as to how to quicken the execution.

III, III, 445 [ОтнELLO] "Now do I see 'tis time": "time" Q1; "true" F, Q2. The reading time could appear a little less consistent than true, but what is appealing for us is that time and true come across as adiaphora ('it is time for revenge', or/and 'it is true that Desdemona is a traitress'). In this way, we see Othello has absorbed the poison of Iago and embraced his timeframe, in which the truth is not actually absent, only compressed.

IV, II, 53-55 [OTHELLO] "but alas, to make me / the fixed figure for the scorn of time / to point his slow and moving finger at!". F Q have "time of scorn", Neill emends. (Note 58) Furthermore, instead of "moving", Q1 has "unmoving finger" ("fingers" Q2). Here, the verses are not entirely clear. Othello may be saying "time mocks me, as he points his slow, and imperceptibly moving finger in my direction'. It may also be possible that "time of scorn" means 'the age of scorn': "We take 'the time of scorn' to be an impersonation of the scornful spirit of the epoch, and alluding to the image of Time which many ancient clocks bore. To our minds the combination 'slow, unmoving' serves exactly to describe the hand of a dial, with its onward-stealing yet apparently still finger; so that, in every way, the idea of the clock is presented to the imagination by this passage". (Note 59) What is interesting is how Othello feels the pressure of time, time which Iago has under his absolute control.

\section{Provisional Conclusion}

We have seen that the role of the villain Iago in Othello is characterized by an active intervention on time. Time is a kind of accordion, which may be expanded and contracted by he who masters it. A master of time is a master of narration as well: to know the rules and necessities of the unfolding of events, in a segment of time, entails a rare form of skilfulness, but not at all 'magical'. Iago is a satiric realistic thinker, and his shrewdness is a very insightful vision of things, persons, and event, both past and future. He recognizes the unavoidability of some sorry loci communes of contemporary merciless society; he is an impassive anthropologist. We may add that Iago is aware of the relativity of time, an elastic rather than stiff entity. Thus, such a plastic relativity allows many a manipulation for one's own interests. However, this requires alertness of mind. Alternatively, you must just be the supreme playwright of all time. (Note 60)

\section{References}

Adamson, J. (1980). "Othello" as tragedy: some problems of judgement and feeling. Cambridge: Univ. Press. https://doi.org/10.1017/CBO9780511553066

Anzi, A. (2000). Iago o della malinconia. In Lombardo (2000), 85-100.

Azzolini, C. (1991). Giraldi, Chappuys e Shakespeare: la fonte e il testo dell'”Othello". Schifanoia, 12, 221-227.

Babb, L. (1951). The Elizabethan Malady. A Study of Melancholia in English Literature from 1580 to 1642. East Lansing: Michigan State College Press.

Bartlett, J. (1894). A New and Complete Concordance or Verbal Index to Words, Phrases, \& Passages in the Dramatic Works of Shakespeare. London: Macmillan.

Berkeley, D. S. (1963). A Vulgarization of Desdemona. Studies in English Literature, 3(2), 233-239. 
https://doi.org/10.2307/449296

Bethell, S. L. (1952). Shakespeare's Imagery: the Diabolic Images in "Othello". Shakespeare Survey, 5, 62-80. https://doi.org/10.1017/CCOL052106418X.008

Bloom, H. (1994). The Western Canon. The Books and Schools of the Ages. New York: Harcourt Brace.

Bradley, A. C. (1962). Shakespearian Tragedy. London: Macmillan \& Co.

Bronson Feldman, A. (1952). Othello's obsessions. American Imago, 9, 147-163.

Bryan, G. B. (1968). Pilgrim at the Shrine of a Saint: John Quincy Adams on Shakespeare. Educational Theatre Journal, 20(4), 516-523. https://doi.org/10.2307/3204996

Budra, P. (2000). "A Mirror for Magistrates" and the "de casibus" Tradition. Toronto-Buffalo-London: Univ. of Toronto Press. https://doi.org/10.3138/9781442670396

Calderwood, J. L. (1989). The Properties of “Othello”. Amherst: Univ. Of Massachusetts Press.

Caponi, P. (2008). La novella del Moro: Cinthio e Shakespeare tra interstestualità e ideologia. In Tempera, Cherchi \& Rinaldi (2008), 131-143.

Clemen, W. (1977). The Development of Shakespeare's Imagery. London: Methuen.

Cowden Clark, M. \& C. (1879). The Shakespeare Key. London: Sampson Low, Marston, Searle \& Rivington.

Cowen Orly, L. (Ed.). (2014). Othello. The State of Play. London and New York: Bloomsbury Arden Shakespeare.

De Armas, J. (1910). Ensayos críticos de Literatura inglesa y Española. Madrid: Librería General de Victoriano Suárez.

Derrin, D. (2017). Rethinking Iago's Jests in "Othello" II. i: "Honestas", imports and laughable deformity. Renaissance Studies, 31(3), 365-382. https://doi.org/10.1111/rest.12219

Elliott, G. R. (1953). Flaming Minister. A study of "Othello" as Tragedy of Love and Hate. Durham (North Carolina): Duke Univ. Press.

Farnham, W. (1971). The Shakespearian Grotesque. Its Genesis and Transformations. Oxford: Univ. Press.

Flatter, R. (1950). The Moor of Venice. London: W. Heinemann.

Freud, S. (1921). Massenpsychologie und Ich-Analyse. Leipzig-Wien-Zürich: Internationaler Psychoanalytischer Verlag.

Furness, H. H. (1886). New Variorum Edition of Shakespeare, VI, Othello. Philadelphia: J. B. Lippincott Company.

Gigliucci, R. (2008). Melanconia Europa: appunti. In A. Gnisci \& N. Moll (Eds.), Studi europei e mediterranei (pp. 33-48). Roma: Bulzoni.

Gigliucci, R. (2009). La Melanconia. Milano: Rizzoli.

Gigliucci, R. (2013). Tragicomico. Napoli: Guida.

Gigliucci, R. (2013). Perfezionamento del lieto fine fra Giraldi Cinzio e Shakespeare. Critica Letteraria, 41(2-3), 613-643.

Granville Barker, H. (1969). Prefaces to Shakespeare. 4. Othello. Love's Labour's Lost. London: B. T. Batsford.

Greenblatt, S. (2005). Renaissance Self-Fashioning. From More to Shakespeare. Chicago \& London: Univ. of Chicago Press. https://doi.org/10.7208/chicago/9780226027043.001.0001

Hackett, J. H. (Ed.). (1863). Notes, Criticisms, and Correspondence upon Shakespeare's Plays and Actors. New York: Carleton.

Hazlitt, W. (1817). Characters of Shakespeare's Plays. London: Hunter and Ollier.

Heilman, R. B. (1956). Magic in the Web. Action \& Language in "Othello". Westport (Connecticut): Greenwood Press.

Hyman, S. E. (1970). Iago: Some Approaches to the Illusion of His Motivations. New York: Atheneum.

Kitzes, A. (2006). The Politics of Melancholy from Spencer to Milton. New York: Routledge.

Klibanski, R., Panofsky, E., \& Saxl, F. (1964). Saturn and Melancholy. New York: Basic Books. 
Kolin, P. C. (Ed.). (2002). Othello. New Critical Essays. New York and London: Routledge.

Lawrence, J. (2000). "Non son io quel che paio in viso": "Othello", Cinthio and "Orlando furioso". In Marrapodi (2000), 119-133.

Lombardo, A. (Ed.). (2000). Memoria di Shakespeare. I. Roma: Bulzoni.

Lord Hall, J. (1999). Othello. A Guide to the Play. Westport (Connecticut) and London: Greenwood Press.

Marrapodi, M. (Ed.). (2000). Shakespeare and Intertextuality. Roma: Bulzoni.

Middleton Murry, J. (1948). Shakespeare. London: Johnatan Cape.

Mishima, Y. (1958). Confessions of a Mask. New York: New Directions.

Morozov, M. M. (1949). The Individualization of Shakespeare's Characters through Imagery. Shakespeare Survey, 2, 83-106.

Muir, K., \& Edwards, P. (Eds.). (1977). Aspects of "Othello". Articles reprinted from "Shakespeare Survey". Cambridge: Univ. Press.

Nicoll, A. (1931). Studies in Shakespeare. London: The Hogarth Press.

Open Source Shakespeare-George Mason University. (2003-2017). Concordance of Shakespeare's Complete Works. Retrieved from https://www.opensourceshakespeare.org/concordance/

Pechter, E. (1999). Othello and Interpretative Tradition. Iowa City: Univ. Press.

Quincy Adams, J. (1863). The Character of Desdemona. In Hackett (1863), 234-249.

Rebora, P. (1047). Shakespeare. Milano: Mondadori.

Rogers, R. (1969). Endopsychic Drama in "Othello". Shakespeare Quarterly, 20(2), 205-215. https://doi.org/10.2307/2869005

Rymer, T. (1693). A Short View of Tragedy. London: R. Baldwin.

Schmidt, A. (1886). A Complete Dictionary of all the English Words, Phrases and Constructions in the Works of the Poet. I. Berlin-London: G. Reimer-Williams \& Norgate.

Scragg, L. (1977). Iago—Vice or Devil? [1968]. In Muir \& Edwards (1977), 48-60.

Serpieri, A. (2003). Otello: l'eros negato. Napoli: Liguori.

Shakespeare, W. (1903). Othello, ed. by H. Clichester Hart. London: Methuen-Arden Edition.

Shakespeare, W. (1958). Othello, ed. by M. R. Ridley. London and New York: The Arden Shakespeare.

Shakespeare, W. (2003). Othello, ed. by N. Sanders. Cambridge: Cambridge Univ. Press.

Shakespeare, W. (2006). Othello, the Moor of Venice, ed. by Michael Neill. Oxford: Clarendon Press. https://doi.org/10.1093/actrade/9780198129202.book.1

Shakespeare, W. (2016). Othello, ed. by. E. A. J. Honigmann. London and New York: Bloomsbury Arden Shakespeare.

Spevack, M. (1968). A Complete and Systematic Concordance to the Works of Shakespeare, III. Hildesheim: G. Olms.

Tempera, M., Cherchi, P., \& Rinaldi, M. (Eds.). (2008). Giovan Battista Giraldi Cinzio gentiluomo Ferrarese. Firenze: Olschki.

Wangh, M. (1950). Othello: the Tragedy of Iago. Psychoanalytic Quarterly, 19, 202-212.

Wilson Knight, G. (1949). The Wheel of Fire. London: Methuen.

\section{Notes}

Note 1. We quote from Shakespeare (2006).

Note 2. It is improper, after all, to talk about a common interpretation; the exegesis of Othello is huge and multifaceted particularly during last decades; we cannot quote such an innumerable number of items; we simply refer to Pechter (1999); Lord Hall (1999); Kolin (2002), particularly the first chapter by Id., Blackness Made Visible. A Survey on "Othello" in Criticism, on Stage, and on Screen, pp. 1-88, with bibliography; Cowen Orly (2014). 
Note 3. See conversely a deconstruction of their love in Elliott (1953), pp. XXX-XXXI.

Note 4. Rebora (1947), pp. 196-199.

Note 5. For the iconography of the Melancholy in relation to Iago, see Anzi (2000), pp. 85-100. The long tradition of Melancholy, culminating in the overarching summa by Burton, includes figures of infamous villains, in addition to flaming geniuses, thinkers, heroes and so on. The bibliography about that is vast; see primarily Klibanski, Panofsky, Saxl (1964); Babb (1951); Kitzes (2006) etc. See also Gigliucci (2008), (2009).

Note 6. "In analysing Iago's nature the first thing we note is that, in comparison with the other characters, he is a highly intellectual—or better, intelligent-man. He towers above all the rest with his fertile, acute and normally far-sighted brain-power": Allardyce Nicoll (1931), p. 94. On the other hand, somebody does not agree with those who deem Iago a very ingenious character: "Increasingly clearly, we realize that his power as a hunter and 'poisoner' derives, not from a splendid intellect, but far more from the particular constitutions of his chosen victims. This is true not only in his relations with Othello, but equally with Roderigo and with Cassio, with Brabantio, even (in a rather different way) with Emilia and Desdemona. In each case Iago is more a catalyst that precipitates destruction than a devil that causes it: without his victims' infirmities-including their propensity to trust him-he is in fact utterly impotent" (Adamson, 1980, p. 74). Actually, Iago "precipitates destruction" abridging the time, as we shall see, but if he were not supremely clever and sly, he could not understand the time, foresee the events.

Note 7. Cf. I, III, 128-170.

Note 8. For 'coitus'.

Note 9. Reading according to Folio and second Quarto; Q1 has "againe”.

Note 10. 'Sure, natural, undeniable'.

Note 11. Hapax in Shakespeare. One "whose conscience does not extend beyond" (Neill).

Note 12. 'Lust'.

Note 13. 'Remains living'.

Note 14. At least since 1950-1952 (Wangh, 1950, pp. 202-212; Bronson Feldman, 1952, pp. 147-163). See Rogers (1969), pp. 205-215; Hyman (1970), pp. 101-121; Thompson (2016), intr. pp. 37, 48; Lord Hall (1999), pp. 80-81 and footnotes pp. 98-99. For an intriguing comparison with the character Claggart in Billy Budd by Melville, see Heilman (1956), p. 37.

Note 15. "Your son-in-law is far more fair than black" (I, iii, 288).

Note 16. See the conclusions about this issue in Neill, intr. Shakespeare (2006), p. 147.

Note 17. Their sensuality, f. i.; on the other hand, just "through the imagery Othello's emotional nature is revealed to us as highly sensuous, easily kindled and interpreting everything through the senses", Clement wrote in his paramount volume (1977), p. 124. About the "colonial attitude" of Iago toward Othello, see Greenblatt, (2005), pp. $232 \mathrm{ff}$.

Note 18. I take the liberty to quote Gigliucci (2013), pp. $56 \mathrm{ff}$.

Note 19. Pechter (1999), p. 59, my emphasis.

Note 20. Unavoidable is the cross reference to the conclusive lines pronounced by Iago, particularly "what you know, you know" (V, ii, 301): both this and the above quotes are (super-serious) parodies of the biblical godly language. An in-depth analysis of Iago's ego is offered by Serpieri (2003).

Note 21. See Freud (1921), p. 81 ff.; Mishima (1958), pp. 8-9.

Note 22. Giraldi Cinthio (1566), p. 318. The vexata quaestio whether Shakespeare was acquainted with the source directly in Italian, or the faithful French translation by Gabriel Chappuys, or with other missing texts in English, or with some verbal tale, has in our opinion no certain answer to this day. The scholars are inclined to prefer the former hypothesis; see recently Azzolini (1991), pp. 221-227; Lawrence (2000), p. 133; Caponi (2008), pp. 131-143; Neill, intr. Shakespeare (2006), p. 22. Conversely, for Measure for Measure we have many intermediaries between Giraldi and the Bard: let me quote Gigliucci (2013).

Note 23. Remember that in 17 th Century Italian effeminato meant 'committed to love', thus anti-heroic, the opposite of a warrior.

Note 24. See Furness (1886), pp. 5-10; Neill, intr. Shakespeare (2006), p. 197 etc. It is conceivable that the 
meaning of line 20 simply refers to Cassio's nature of a womanizer (the incongruous wife may be intended for generally 'woman'). Either way, the double-entendres and the dissimulation ( $\neq$ mendacity) are typical of Iago.

Note 25. Cf. Hyman (1970), p. 104; Calderwood (1989), p. 122.

Note 26. "And yet, there is one driving power in Iago, one single irresistible and uncontrollable impulse: his passion for play-acting": Flatter (1950), p. 23

Note 27. See Scragg (1977), pp. 48-60; Farnham (1971), pp. 143-151.

Note 28. Bethell (1952), pp. 62-80, 70.

Note 29. "A kind of bloodhound. [...] Spartan may = unmoved, impassive, inhumanely determined" (Honigmann in Shakespeare 2016 ad loc.); "But [...] a sarcastic quibble on his display of 'Spartan' courage is probably involved" (Neill in Shakespeare 2006, ad loc.); Ridley (in Shakespeare 1958 ad loc.) felt "that we must be missing some allusion".

Note 30. Cf., concerning this perspective, Lord Hall (1999), pp. 130 f. ("Metadramatic") and notes 98-100 p. 145 .

Note 31. Calderwood (1989), p. 122 (cf. pp. 113-134).

Note 32. See Rymer (1693), p. 146. The comic and comedic side of Othello has been detected by many recent scholars: see Lord Hall (1999), pp. 35 f. and bibliographical notes 33-37, p. 58.

Note 33. The problem of the time displayed in Othello has been discussed exhaustively; the particular and tortuous theory of "double time" excludes Iago's actions from the previous longer span of days, as correctly suggested by Bradley (1962), $6^{\text {th }}$ lesson, critical note n. 1. Cf. always Neill, intr. Shakespeare (2006), pp. $33 \mathrm{ff}$.

Note 34. This idea, the crux of my short essay, is not completely new (and what is like so, in Shakespearian criticism?); cf. f. i. the classical Murry (1948), pp. 318 ff.; or Wilson Knight (1949), p. 113 - I simply try to develop my intuition Cf. also the remark by Heilman (1956), p. 101: "Iago's instinct for destructive power finds outlet as well as tide: he works to speed up or slow down the actions of others, so that the pace of time is a symbolic marking of the life he has tampered with". Granville Barker (1969) offered incisive considerations about the "contraction of time" in Othello, but in reference specifically to the play's time (pp. 10-12). De Armas (1910) was close to our interpretation of time: "viene á la mente la idea terrible de que tal vez [Desdemona] no fué adúltera, porque no tuvo tiempo de serlo... A lo menos, lógico era que algún día, pasado el primer impulso de su entusiasmo histérico, volviese de verdad sus ojos á Cassio, como creyó Yago, porque era más bello, más blanco, más joven, sobre todo, y, además, tan bueno como el moro de Venecia..." (pp. 139 f., my italics).

Note 35. The motive of the obliged spotless purity of married women is present in the introductory speech of the story-teller in the tale of Giraldi Cinthio (1566): "credo io bene, che sia in arbitrio di honesta donna, quando si sente di tal fiamma accesa, voler più tosto morirsi, che, per dishonesta voglia, macchiare quella pudicitia, che debbono osservare le donne, come un candido Armelino [Ermine], senza punto di macchia" (p. 317). The follow-up utterance is intriguing too: "Et credo, che meno errino quelle, che, sciolte dal santo legame del Matrimonio, espongano i corpi loro, a diletto di ognuno, che donna maritata, che con un solo adulterio commetta" (ibid.). In Othello, the most guilty women would refer to Desdemona and Emilia, for even though they are married women, the strumpet Bianca in love with Cassio is still more virtuous than they are. See Bianca's proud reply to Emilia at $\mathrm{V}, \mathrm{i}, 120 \mathrm{f}$.

Note 36. Derrin (2017), pp. 365-382. See also Heilman (1956), pp. 46-50, and Lord Hall (1999), pp. 72-75.

Note 37. For the "animal grotesquery" of these sexual images, see Farnham (1971), pp. 145-147. "One of the means which Shakespeare employs to indicate the gradual hold Iago develops over Othello's mind is the growing infection of his speech by Iago's vocabulary. [...] Iago's habitual conception of man as animal produces in Othello's mind a hideous vision of a bestial world inhabited by goats, monkeys, toads, crocodiles, blood-sucking flies and poisonous snakes" (Shakespeare 2003, intr. by Sanders p. 33). See, prior to this, Morozov (1949), pp. 83-106: 84 ff.

Note 38. Thus, polluting that flesh, making it a carrion; cf. f. footnote.

Note 39. The explicative footnote by Honigmann (Shakespeare 2016 ad loc.) seems to us too simplistic: the flies "receive life, are inseminated, i.e., with the blowing of the wind". The verb to blow in the meaning of "to deposit eggs on or in (a place)'; 'to fill with eggs', said particularly of flies, is documented by $O E D$ ad voc. n. 28, with Shakespearian examples. Clichester Hart in Shakespeare (1903) paraphrased "blowing" as 'fouling'. In the Complete Dictionary (Schmidt, 1986) at point 6 of item blow we read: "to foul, to sully with ordure, applied to 
flies" and the usual examples follow, then the text continues: "also, to deposit eggs", and we have the quotation of our line from Othello and Love's Labours Lost V, ii, 410-411: "these summer-flies / have blown me full of maggot ostentation". Sanders annotates "quicken ...blowing: come to life merely with the depositing of larvae" (Shakespeare, 2003, p. 165).

Note 40. Giraldi Cinthio (1566), p. 317.

Note 41. Even the meaning of this apparently innocent word, quality, is controversial: cf. at least the old debate testified by Furness (1886) ad loc. "Quality" has been interpreted as 'profession', 'individual nature', 'distinctive grain or personal propriety', 'the Moorish complexion and/or his military profession', or even the black colour of Othello's skin. Particularly, the President Quincy Adams agreed with those who had interpreted "very quality" as "the Moorish complexion of Othello", his physical sex appeal (Quincy Adams, 1863, pp. 234-249, 241).

Note 42. Shown as well by the reading "rites" in the v. 255: "the rites for why I love him are bereft me", if Othello goes to the war without his wife. The lectio shared by Quartos and Folio was emended in "rights", more decorous, even though for the public in a performance it is difficult to distinguish one from the other. Rites, alluding to the consummation of matrimony, would be too vulgar for the 'sublime' Desdemona (see Berkeley, 1963, pp. 233-239). Nevertheless, consider her wonderful "simpleness" (v. 244), and every possible sexual hint in her mouth becomes light and honest. Conversely, the Q's reading "a world of sighs" (I, iii, 159) instead of "a world of kisses" of F, was considered since Pope's age too improper not to be a mistake, whereas it may be a very intriguing author variant (cf. Greenblatt 2005, p. 300, n. 26). On the other hand, some scholars have been less indulgent with the character of Desdemona: cf. f. i. Quincy Adams (1863), passim (see Bryan, 1968, pp. 516-523, 520); De Armas (1910), pp. 138 f.; Flatter (1950), pp. 99 ff.; Nicoll (1931), pp. 87 ff.

Note 43. Probably implicit reference to penis, anyway a double entendre. Noticeable, again, that this exclamation is omitted by unscrupulous Q, just as below the disgusted "Pish".

Note 44. In a sexual meaning, of course.

Note 45. 'To fondle with the fingers'.

Note 46. Adamson (1980), p. 66.

Note 47. Our italics.

Note 48. Hazlitt (1817), pp. 54-56, also quoted in Furness (1986), p. 411.

Note 49. Sources: Spevack (1968); Bartlett (1894), adding the online resource offered by Open Source Shakespeare (2003-2017).

Note 50. Honigmann in Shakespeare (2016) ad loc.

Note 51. Cf. Neill in Shakespeare (2006), p. 240.

Note 52. Cf. Ridley in Shakespeare (1958) ad loc.

Note 53. And see below, II, iii, 287 “As the time, the place and the condition" etc., the Iago's hypocrical talk with Cassio himself.

Note 54. Cf. Neill in Shakespeare (2006), p. 278

Note 55. Cassio, obviously.

Note 56. Reading of F and Q2; Q1 has "muttering", lectio facilior, "since Othello is not muttering, though he is mammering in the sense of hesitating, shilly-shallying" (Ridley in Shakespeare 1958 ad loc.).

Note 57. Reading of Q1; F and Q2 have "Trust me", to avoid the imprecation, even if it is a "mild oath" (Honigmann in Shakespeare 2016 ad loc.).

Note 58. Neill in Shakespeare (2006), ad loc.

Note 59. Cowden Clarke (1879) quoted by Furness (1886), p. 260.

Note 60. See Bloom (1994).

\section{Copyrights}

Copyright for this article is retained by the author(s), with first publication rights granted to the journal.

This is an open-access article distributed under the terms and conditions of the Creative Commons Attribution license (http://creativecommons.org/licenses/by/4.0/). 